University of South Carolina

Scholar Commons

4-1975

\title{
Egypt's Socialism and Marxist Thought: Some Preliminary Observations on Social Theory and Metaphysics
}

Shahrough Akhavi

University of South Carolina - Columbia, akhavi@sc.edu

Follow this and additional works at: https://scholarcommons.sc.edu/poli_facpub

Part of the Political Science Commons

Publication Info

Published in Comparative Studies in Society and History, Volume 17, Issue 2, 1975, pages 190-211.

http://journals.cambridge.org/action/displayJournal?jid=css

(C) 1975 by Cambridge University Press

This Article is brought to you by the Political Science, Department of at Scholar Commons. It has been accepted for inclusion in Faculty Publications by an authorized administrator of Scholar Commons. For more information, please contact digres@mailbox.sc.edu. 


\title{
Egypt's Socialism and Marxist Thought: Some Preliminary Observations on Social Theory and Metaphysics
}

\author{
SHAHROUGH AKHAVI \\ University of South Carolina
}

\section{THE PRIOR SIGNIFICANCE OF UNITY}

Since 1952 the elaboration of Egyptian ideology has constituted a source of conflict between the regime and the left/right opposition. In trying to capture the ideological center, the regime has inevitably drawn itself into the maelstrom of public contention characterized by mass conformity, intimidation, purges, arrests, show trials and incarceration of all who fundamentally question the principles of the leadership. Democratic cooperative socialism ('Arab socialism') is the official ideology, and a spate of books and articles have been published on its significance for Egyptian politics. Despite all these efforts, confusion still tends to reign over this concept, both among Egyptians themselves, and outsiders studying it.

It is essential to build toward a definition of Arab socialism in its Egyptian variant. It seems to mean, among other things, and first of all, unity of all Arabs: the establishment of unity both inside and outside the country in the struggle for the abolition of expoitation of the Arab (working) masses. The parentheses around the term, working, indicates the occasional and even casual attitude of the regime to the social basis of its revolution. More often than not, Egyptian spokesmen invoke the masses as a whole, thereby demonstrating symbolically their preference for unity over equality

Without question, the more prior of the twin concepts of unity and egalitarianism (i.e. the abolition of exploitation), both of which are embedded at the core of the Egyptian interpretation of Arab socialism, is unity. It is the mutual identification of Arabs in terms of race, ethnicity, religion, language, region, as well as common sense of purpose, shared commitment to a particular social and political community above and beyond all lesser commitments, a willingness to continue to coexist in the framework of this commitment, and solidarity in the quest for their greater destiny which, to Egyptians, make possible the attainment of egalitarianism. 
By contrast, the abolition of man's exploitation of his fellow man, the levelling of social stratification, the ending of social alienation-these are seen to be epiphenomena, deriving logically as effects from Arab national unity and identity. The argument of Egyptian theoreticians carries the strong implication (and occasionally forthright assertion) that equality is a dependent variable.

It might appear that to anatomize Egypt's version of Arab socialism in this manner does violence to a body of thought and action which Arabs intend to be viewed as a whole. However, it will be seen that Arab socialism's Egyptian advocates follow precisely this method in their attempt to respond to their critics. Arab socialism, to Egyptian spokesmen, is admittedly an ideology whose basis and 'point of departure' [muntaliq] is nationalism. ${ }^{1}$ The argument concerning Arab socialism insists that an Arab nation ${ }^{2}$ exists, and this existence serves as the fundamental reference point for everything that follows. Once unity is established, anchored in the bedrock of nationality everything necessary for the construction of socialism will come to hand. This is not to deny, the argument runs, that the construction of socialism in the Arab nation will be a difficult task. But it is to say that without devotion to the variables associated with nationality and nationalism, it is hopeless for Arabs to think of building socialism in the first place. Indeed, no revolution can be progressive in the Arab world if Arabs are divided artificially into the territorial entities that currently demarcate nation-states from one another. Such, at least, is the reasoning of Egyptians advocating Arab socialism. Says one leading interpreter:

This means that there [must] be one Arab socialist revolution, not a number of socialist experiences or revolutions. The difference is clear: the Arab socialist revolution realizes Arab unity and socialism together, [whereas] a number of revolutions [in different Arab states] achieve what they can while division and separation continue. In other words, ultimately, as far as the indivisibility of the Arab destiny is concerned, they [i.e., several Arab revolutions] are not progressive and will find themselves willy nilly standing on the very same foundations made firm by capitalist imperialism. ${ }^{3}$

1 'Ismat Sayf al-Dawlah, Al-Tariq ila al-Ishtirakiyyah [The Path to Socialism] (Cairo: Dar al-Nahdah al-'Arabiyyah, 1968), pp. 5-8. In a revealing passage the author writes: 'The point of departure of nationality for [Arab] socialism means that the objective of the Arab socialist revolution is the liberation of all the Arab masses from exploitation', i.e. nationality effects equality. $\mathrm{Cf}$. the traditional Marxist position that the point of departure for all analysis is contradiction-i.e. contradiction effects equality.

2 The term 'Arab nation' [al-watan al-'arabi] signifies a unitary political and social system for all Arabs from the Atlantic to the Gulf. The notion of its existence in reality illustrates the fallacy of reification or misplaced concreteness. As a concept, Arab nation carries a potent appeal. But the transformation of concept into praxis is a task that still waits to be done.

${ }^{3}$ Sayf al-Dawlah, p. 8. Emphasis supplied. Division is abhorrent, in short, because it is that upon which capitalism thrives. Unity, on the other hand, is laudable because it comprises the nourishment for socialist construction. Sayf al-Dawlah is of course echoing exactly the sentiments of Michel 'Aflaq, co-founder of the Ba'th Party (a source of profound inspiration for Egypt's socialism), when he wrote that 'any viewpoint or remedy of the vital difficulties of the Arabs, either in part or in toto, which does not emanate from the axiom "The Unity 


\section{SHAHROUGH AKHAVI}

Rather than proceeding by close argument to demonstrate the actual existence and necessity of Arab unity, passages such as these assert that ethnicity, religious and linguistic identity and the like determine the successful or unsuccessful construction of socialism. This may be contrasted to the focus on the mode of production as the starting point for an analytical examination of the building of socialism in any society. Without questioning the tremendous impact of nationality-based factors in explaining political dynamics in human societies, one cannot help but be struck at the disregard for that which European socialists have traditionally considered the heart of the entire matter: examination of social systems on the basis of their organization of productive relations and the growth of productive forces, the social division of labor, and the separation of large segments of society into mutually hostile classes. Here, then, is a major distinction between the perspective of European and Egyptian socialists. 4

Why is it that there must be a single Arab socialist revolution and not a series of socialist transformations in individual nation-states? What, after all, does nationality have to do with this essentially secular process? The answer that is normally given is along the following lines: the Arab masses demand a single, united effort; their Arabness is an emanation of their true feelings and the heritage of the past. However, Arab socialists have never successfully answered the challenge thrown out at them by the then First Party Secretary of the CPSU, Nikita Khrushchev, during the official ceremonies marking the completion of the construction of the first stage of the High Dam at Aswan in May 1964: what would the future of the Bolshevik Revolution have been had Lenin said to the Great Russians, 'unite against everyone; you are the best of people, the salt of the earth'? Khrushchev demanded of his startled Egyptian hosts how socialism based on nationality could be possible if its acceptance in the Russian case would have meant relegating the Ukrainians, White Russians, Uzbeks, and so on to a permanent inferiority. He upbraided the Egyptian and other Arab speakers at the ceremony (Ben Bella, Muhammad 'Abd al-Salam 'Arif) for constant references in their speeches to Arab unity. But where do the Soviets fit in? Khrushchev demanded. Must they be excluded? Lenin called for unity on a class basis, and Arab capitalists and feudalists are not the brethren of the Arab proletariat. 'It is easier to eat bags of salt' than to unite with the non-working elements of the Arab world. ${ }^{5}$

of the Arab People' is an erroneous outlook and an injurious cure'. 'Aflaq, Ma'rakah alMasir al-Wahid (Beirut, 1953), p. 19, cited in Gordon H. Torrey, 'The Ba'th-Ideology and Practice,' The Middle East Journal, Vol. 23, 4 (Autumn 1969), p. 448.

4 For an excellent discussion of the reaction in the Arab world to the Marxist explanation of historical development as a function of class struggle and the Arab preference for explaining this development in terms of 'the external confrontation of nationalitarian groups', see Maxime Rodinson, 'Dynamique interne ou dynamique globale: l'exemple des pays musulmans', Cahiers Internationaux de Sociologie, XLII (Jan.-June 1967), pp. 27-47.

5 For these remarks, published by the Egyptians (albeit inconspicuously, on the obituary page), see al-Ahram, May 17, 1964. 
Khrushchev seemed to be implying that the stress on ethnic unity might be less relevant for the construction of socialism than as a framework for the demogogic manipulation of political action in general. According to the reasoning behind this implication, therefore, the importance of unity resides in the role unification plays in the power-political aspirations of certain elites. 6

Thus far, it has been argued that Egypt's socialist theoreticians consider nationalism, nationality and national consciousness as the ne plus ultra of their system. The break with Marxism and neo-Marxism could not be clearer. Lenin, for example, in one of his earliest tracts, ridiculed the notion of a 'Russian' road to socialism that could bypass capitalism.7 Marx did, at one point, raise the possibility that the Russian commune might serve as the mechanism by which Russian society might move into a postcapitalist stage. But this was an isolated instance and surely does not represent Marx's thinking in its total frame and system. ${ }^{8}$

It is true that the Marxist-Leninists have since gone through a number of stages in their thinking on the role of nationalism or nationality in the building of socialism. ${ }^{9}$ But even the Yugoslavs, whose revisionism largely brought about Khrushchev's ideological innovation of 'separate paths to socialism' in 1955 and 1956 consider the national phenomenon as a less than decisive factor. To the Yugoslavs the doctrine of separate paths, far from glorifying the 'Yugoslav Idea' or nation, is an instrument to maintain distance from Soviet intervention in their country. Egyptians, on the other hand, tend to view nation, nationality and nationalism as ends in themselves. While the Romanians, to take another example from Eastern Europe, demand autonomy from the Bolshevik-Soviet model, they place the emphasis not upon ethnicity but upon ecological peculiarities that make it difficult for them to follow that model. Similarly, when the term 'national communism' came into use in connection with events in Poland and Hungary in the mid-fifties, observers seemed to agree that the concept signified the absence of certain structural characteristics in these societies,

${ }^{6}$ Here, Arab unity becomes, like religion for Marx, the opiate of the masses, as it were.

7 See Lenin's What the 'Friends of the People' Are and How They Fight Social Democracy (1894) in his Works, numerous editions. Although later in his life (say 1915), he felt Russia to be ripe for revolution because of its backwardness-in itself a paradox-he did not feel that a Russian revolution by itself could survive. Cf. his article, 'On the United States of Europe Slogan', August 23, 1915, in Selected Works (London: 1947), Vol. I, pp. 630 ff.

8 Marx and Engels, joint preface to the second Russian edition of the Communist Manifesto, 1882: "if the Russian Revolution becomes the signal for a proletarian revolution in the West so that both complement each other, the present Russian common ownership of land may serve as the starting point for communist development'. Cited in George Lichtheim, Marxism: An Historical and Critical Study (New York: Praeger, 1965), pp. 327-8.

${ }^{9}$ See, for example, V. L. Tiagunenko, 'Sotsialisticheskie Doktriny Obshchestvennogo Razvitiia Osvobodivshikhsa Stran' [Socialist Doctrines of Social Development in the Liberated Countries], Mirovaia Ekonomika i Muzhdunarodnye Otnosheniia, No. 8 (Aug. 1965), pp. 79-86; G. Mirskii and T. Pokataeva, 'Klassy i Klassovaia Borba v Razvivaiushchikhsa Stranax' [Classes and the Class Struggle in the Developing Countries], ibid., nos. 2 and 3 (February and March 1966), pp. 38-50; 57-70 respectively. 


\section{I94 SHAHROUGH AKHAVI}

which absence militated against a Stalinist model of socialist construction.

But the Egyptian socialists adopt another view toward 'separate paths' To them, nationalism and unity lie at the heart of what makes the socialist engine run. They are not the lubrication that contains and smoothens the process but rather the power source itself. This is the difference, between nation variables as the energy supply as opposed to nation variables as comprising the engine block within which this energy is given off. Thus, if one may carry this metaphor to the end, European socialist advocates of separate paths seem to mean that the suspension in which the whole system rests must be less viscous than that in which the Soviet model has been suspended. Egyptian socialist advocates of separate paths, however, feel that the system itself cannot run on the basis of cleavages in society that must work themselves out through mutual collision and struggle. The power source must be replaced. In the end, European socialists tend to view their differences with the Soviets as differences in degree: the common denominator is still dialectics and contradiction as the motor of history. The Egyptians view their differences with all other socialists as differences in kind, stressing the indivisibility of the Arab people as the engine.

For the Egyptian socialists, socialism consists of liberation of all Arabs from exploitation. Their writers have addressed less attention to the definition of exploitation and the social basis of politics. In the need to condemn colonialism and neo-colonialism, the Egyptian theorists tend to merge practically all rank-and-file Arabs into the 'exploited' ranks. It is true that 'feudalists' and 'comprador bourgeoisie' are excluded from the Arab populations to be embraced by Arab unity and nationalism. But it is not made clear how one can harmonize and reconcile the different interests of the petite bourgeoisie, the 'military' bourgeoisie (a Soviet innovation after 1967), and Bottomore's 'new middle classes'.10 To what extent the typical Egyptian Arab is an excellent source for socialist cadres in Egypt is a question that badly needs asking by the establishment theoreticians. Some of the more perceptive of these, such as former cabinet figure,

10 Tom B. Bottomore, Classes in Modern Society (New York: Pantheon Books, 1966), pp. $23 \mathrm{ff}$. As examples, he cites 'office workers, supervisers, managers, technicians, scientists, and many of those who are employed in providing services of one kind or another .... For a discussion of the utility of the concept of 'new middle class' (originally proposed by Manfred Halpern, The Politics of Social Change in the Middle East and North Africa [Princeton: Princeton University Press, 1963]), see Amos Perlmutter, 'Egypt and the Myth of the New Middle Class', Comparative Studies in Society and History, IX, 4 (October 1967); Manfred Halpern, 'Egypt and the New Middle Class: Reaffirmations and New Explorations', CSSH, XI, 1 (January 1969); Perlmutter, 'The Myth of the Myth of the New Middle Class: Some Lessons in Social and Political Theory', CSSH, XII, 1 (January 1970); Halpern, 'The Problem of Becoming Conscious of a Salaried New Middle Class', ibid. For another approach, utilizing the concept of neo-patrimonialism and rejecting the concept of class as inapplicable in Egypt's case, see Shahrough Akhavi, 'The Egyptian Political Elite', in Comparative Political Elites in the Middle East: Seven Cases, ed. Frank Tachau (Cambridge, Mass.: Schenkman. 1975), pp. 70-117. 
Kamal al-Din Mahmud Rif'at, have been uneasy about the regime version of socialism (which they themselves have helped elaborate!). But few analysts have inquired more systematically into the social composition of the Egyptian masses to analyze which sectors are revolutionary and which are apathetic or counter-revolutionary. There is a need for further efforts in Egyptian sociology to differentiate among:

(1) the military (and within it, various sub-units or groups);

(2) the 'national bourgeoisie' and 'national capitalists';

(3) the 'petite bourgeoisie';

(4) the middle rural sectors;

(5) the revolutionary intelligentsia;

(6) the urban professionals;

(7) the administrative stratum or forces;

(8) the industrial proletariat;

(9) the small and poor peasantry;

(10) agricultural laborers;

(11) the lumpenproletariat;

(12) tribal or nomadic groups. ${ }^{11}$

To the contrary, the analyses of Egypt's interpreters of Arab socialism seem to perpetuate the classic and medieval Islamic mode of both intuitional and a priori 12 thought; this has hampered serious Egyptian scholarly work in social science inquiry. The dearth of a posteriori reasoning and sociological method may, at worst, lead to the substitution of assertion and polemic for fact and logic. To borrow an image from geometry, this resembles the use of the very theorem one is trying to prove in the form of a hypothesis somewhere in the proof itself. In this case, the theorem is that the achievement of Arab unity will result in socialism. In the process of proving this, a short cut is taken, and it is assumed that by and large the Arab people have common interests due to their exploitation by internal overlords and external imperialists; they yearn to expunge this exploitation; they feel that unity will make this possible ... and suddenly it is asserted that hence [sic!], once they attain their unity, no more exploitation will exist, socialism will be achieved (quod erat demonstrandum!). This pro-

11 The Egyptian socialists facilely place these categories into the 'alliance of the popular working forces' - a formula indicating a broad coalition of 'progressive' elements in the society. Excluded from the alliance are members of the former royal house, landed magnates, comprador and grand bourgeoisie.

12 'A priori points to notions, propositions, or postulates that are considered true or necessary irrespective of experience or anterior to it; in other words, not derived from experience and yet considered valid'. Arnold Brecht, Political Theory: The Foundations of Twentieth Century Political Thought (Princeton: Princeton University Press, 1959), p. 99. Good sociological analysis and a priori thought are not necessarily mutually exclusive. But the process must be rigorous; this is why the famous Egyptian man of letters, Dr. Louis 'Awad, has characterized post-1952 Egyptian social theory, political thought, economic analysis and moral philosophy as shabby. See his essay, 'Cultural and Intellectual Developments in Egypt Since 1952', in Egypt Since the Revolution, P. J. Vatikiotis, ed. (New York: Praeger, 1968), p. 156. 
cedure skips the crucial step of demonstrating how the removal of the twin sources of exploitation over the masses (internal overlords) and the upward bound, socially mobile middle sectors (external imperialists) will solve the tension between precisely these two social groups. ${ }^{13}$ It is, after all, possible to attain unity of consciousness of ethnic identity and culture without attaining unity of interests among the diverse corporate groups embraced by that culture.

It will be seen later, below, that despite keen interest among Egyptian intellectuals in problems of political theory and philosophy, one will need to look long and hard to find a systematic and coherent ideological statement of the regime's principles and objectives. Despite the significance of democratic cooperative socialism to the regime, it is odd that the current body of scholarship produced by the country's intellectuals is couched in very general and dogmatic terms. Thus, even the Egyptian socialists themselves may be confused about the meaning of democratic cooperative socialism ${ }^{14}$ the construction of which is taking place under the aegis of the 'popular alliance of the working forces'.

The foregoing analysis of Egyptian interpretations of socialism accords with earlier studies reflecting the lack of concern with analytical rigor in fashioning an ideology. 15 According to one scholar, 'formal ideology' is 'relatively unimportant'. ${ }^{16}$ This is not to say that concern is lacking to explain politics in terms of legitimizing ideas. But these ideas have been turned toward the negative task of dispelling positions and concepts judged to be hopelessly obsolete, antediluvian and counterproductive to development. Beyond this the Egyptian military regime is unwilling to go, and it has even been hostile to intellectuals and to innovative ideologi-

${ }^{13}$ Consider the following: 'The first step in Arab socialism is justice and sufficiency, plus the possibility of measures of revolutionary interaction in a peaceful atmosphere, unsullied by the violence of blood and not made insomniac by the spectors of executions! The first step in communism is punishment and revenge, because the bloodiness of the struggle among classes, in communism's view, is an inescapable necessity'. Muhammad Hasanayn Haykal, 'Nahnu wa al-Shuiu'iyyah' [We and Communism], al-Ahram, August 4, 1961. What one wants to know is why and how socialism for the Arabs consists from the very start of justice and sufficiency.

14 The term has been borrowed, without acknowledgment, apparently, from a widely circulated lecture given by the Iraqi professor of history, Dr. 'Abd al-Rahman al-Bazzaz, to the Arab Renaissance Club in Baghdad in January 1952. Bazzaz contended that the Arab nationalist movement of the 1930 s and 1940 s already contained its 'democratic', 'socialist', 'popular' and 'cooperative' elements. For English translation of this lecture, see 'Islam and Arab Nationalism' [Al-Islam wa al-Qawmiyyah al-'Arabiyyah], in Die Welt des Islams, n.s. III (1954), pp. 201-18, esp. p. 214. The first official use of the term, democratic cooperative socialism, came on November 1, 1957, in the decree of the President of the Republic establishing the National Union.

${ }^{15}$ Leonard Binder, 'Nasserism: The Protest Movement in the Middle East', in The Revolution in World Politics, Morton A. Kaplan, ed. (New York: John Wiley, 1962); Malcolm Kerr, 'Arab Radical Notions of Democracy', St. Antony's Papers, No. 16 (Middle Eastern Studies, No. 3; London: Chatto and Windus, 1963), pp. 9-40.

16 Binder, 'Egypt: The Integrative Revolution' in Political Culture and Political Development, Lucian Pye and Sidney Verba, eds. (Princeton: Princeton University Press, 1965), p. 445 . 
cal initiatives in general.17 More appropriate in understanding its role and function in Egyptian society is the candidly pragmatic approach of the regime to it as a mechanism of rule. ${ }^{18}$

\section{MAN AND THE CONCEPT OF FREEDOM}

If egalitarianism does follow from Arab unity and nationalism, so, too, do Egyptian socialists insist that freedom emanates from that unity. The Arab socialist position is that freedom varies in its meaning from one social system to another. Today, Egyptian socialist theoreticians are prone to attack freedom in the West and in Soviet-type systems in terms of social and political deficiencies respectively. Liberal democracy is defective from the perspective of social justice; Marxist and Soviet democracy, by contrast, have violated man's individual liberty. Arab socialism, according to this line of thinking, nicely meshes the strong points of each of these.19 The philosopher, 'Ismat Sayf al-Dawlah, for example, approvingly cites the Soviet handbook, Fundamentals of MarxismLeninism. Its editors and contributors, he notes, conclude that while philosophers have debated the question of freedom ad infinitum, they have always reached erroneous conclusions. But the Egyptian himself then adds that what is true of philosophers is not so for the common man. The common man states: 'I am free and do what I wish'.20

One cannot help but feel that the Egyptian is arguing that this is the reaction of the Arab Muslim common man. And yet, this individual has rarely thought in such patterns. He is free in the sense that he meets his God on the basis of equality with respect to other Muslim men. But as is

17 Is this the typical attitude of the military in general? Napoleon's contemptuous sobriquet of 'idéologue' that he attributed to the French intellectuals of his time comes to mind. He meant to distinguish men of action from others. Thus, the term 'ideology' was coined with the stigma that a military leader attached to it as the idle activity of do-nothing civilians. On the genesis of the term, see George Lichtheim, The Concept of Ideology and Other Essays (New York: Vintage Books, 1967), esp. pp. 4-5.

${ }_{18}$ This is clearly implied in the following passage in President 'Abd al-Nasir's address to the opening session of the Preparatory Committee of the National Congress of Popular Forces, Nov. 25, 1961: 'Many people say we have no theory, we would like you to give us a theory. What is the theory we are following? We answer, a socialist democratic cooperative society. But they persist in asking for a clearly defined theory. I ask them, what is the object of a theory ? I say that I was not asked on July 23rd to stage the revolution with a printed book including my theory. This is impossible. If we had stopped to write such a book before July 23rd, we would never have succeeded in carrying out two operations at the same time. Those who ask for a theory are greatly complicating matters. This is torture'. Cited in Gamal Abdel Nasser, President Gamal Abdel Nasser's Speeches and Press Interviews, Jan.-Dec. 1961 (Cairo: Information Department, 1961), p. 389. Emphasis supplied.

19 For a major exposition, see Mustafa Abu Zayd Fahmi, Fi al-Hurriyah wa al-Wahdah wa al-Ishtirakiyyah [On Freedom, Unity and Socialism] (Alexandria: Dar al-Ma'arif, 1968), pp. 17-264.

20 'Ismat Sayf al-Dawlah, Usus al-Ishtirakiyyah al-' Arabiyyah [Foundations of Arab Socialism] (Cairo: al-Dar al-Qawmiyyah li al-Taba'ah wa al-Nashr, 1965), p. 133. The title of this work suggests that it was meant to be the Egyptian Arab socialist response to the Soviet guide, Fundamentals of Marxism-Leninism (first edition 1959). Reinforcing this impression is the author's constant reference to the Soviet work. 
well known, the socialization patterns in Islamic civilization stress the subordination of one's own will to that of higher authorities: God, the Prophet, religious leaders, one's elders. It would be a wonder if Muslim man's visceral reaction were to be as Sayf al-Dawlah suggests; or at least, it would be odd to think of him making this statement as a secular credo. The point is that politics and religion are so intermingled in his mind that freedom for him means freedom within the fold to be a good member of the community. It would thus be freedom to continue as part of, rather than freedom to break away from, the community. In the last analysis, this distinguishes freedom as a dynamic factor from freedom as a passive, inert one.

Nevertheless, Arab socialist analysts in Egypt broadly imply that it is the Western approach to freedom (as a dynamic factor) that equips the new Arab man's consciousness. Man is at the core of Egypt's socialism (al-'unsur al-awwal) and 'has the right to a free, noble, blessed life ...'21 Passages such as these reveal the Western education of their authors, whose experience with liberalism, Marxism and existentialism has led them to interpret their society in terms of the categories of thought central to those philosophies. This is natural, of course, and there is certainly nothing wrong with it. The problem that Egypt's Arab socialism has encountered is the great disparity between the habits of the masses and the exercise of freedom in the deep sense intended by Western democratic theory, whether liberal, Marxist, or social democratic.

What emerges from all this is that freedom in Egypt's socialism carries the theoretical claim that man takes a stand on an issue as an individual. This becomes clear after reading what may be called the 'mainstream' of Egyptian socialist literature. Munif al-Razzaz states in irrevocable terms that 'every political system must have as its objective the individual'; that 'the objective of society is to realize the potentialities of the individual'; and that 'the freedoms are the foundation of political rights'.22

Putting it somewhat differently, Professor 'Atif Ahmad of the University of Cairo, has explained the relationship of the individual to the State in Marxian terms. He stresses that separating society and individual and

${ }^{21}$ Mustafa al-Mistikawi, Fi I'dad al-Insan al-Ishtiraki al-'Arabi [On Rearing the New Arab Socialist Man] (Cairo: al-Dar al-Qawmiyyah li al-Taba'ah wa al-Nashr, 1965), pp. 14-5. The emphasis of Egypt's Arab socialism is on serving free man, a theme reiterated time and again. For full treatments, see Sayyid 'Abd al-Hamid Mursi, Insaniyyah al-Ishtirakiyyah al'Arabiyyah [The Humanism of Arab Socialism] (Cairo: Maktabah al-Qahirah al-Hadithah, 1966); 'Abd al-Qadir Hatim, Ishtirakiyatuna Insaniyyah Akhlaqiyyah [Our Socialism is Humanist and Ethical] (Cairo: al-Dar al-Qawmiyyah li al-Taba'ah wa al-Nashr, 1964); Majid Fakhr, Al-Kamal al-Insani Manba' al-Mithaq wa Ghayatuhu [Human Perfection is The Source and Objective of the Charter] (Cairo: al-Dar al-Qawmiyyah li al-Taba'ah wa al-Nashr, 1965); 'Abd al-Rahman Abu al-Khayr, Al-Ba'ith al-Insani li al-Ittijah al-Ishtiraki al-Ta'awuni al-Dimuqrati [The Human Causal Factor for the Orientation of Democratic Cooperative Socialism] (Cairo: Kutub Qawmiyyah, 1961).

${ }^{22}$ Munif al-Razzaz, Ma'alim al-Hayat al-'Arabiyyah al-Jadidah [Benchmarks of the New Arab Life] 4th ed. (Beirut: Dar al-'Ilm li al-Milayiin, 1960), pp. 164 ff., $40 \mathrm{ff} ., 59 \mathrm{ff}$. 
posing the question on which is the more important has led us down the wrong path. Man has always chosen to live within a social system. In fact, it is the social organization and division of production that crystallize his life. 'Life is fashioned according to the laws of production that govern it'. For Ahmad, therefore, it is not the individual and the development of his potentialities to the maximum that is crucial. Rather, he stresses the need to guarantee the life and future of men and to meet their physical and cultural needs. But Ahmad, like al-Razzaz, would agree that the power of the State must be curbed in order to make this possible. ${ }^{23}$ Here, too, the rationalist tradition underlying Western political theory and sociology since the Enlightenment period infuses Egyptians with the inspiration to defend humanism.

Taking another perspective, but equally within the mainstream of Egypt's Arab socialism, Mustafa al-Siba'i looks at the question of freedom from the viewpoint of poverty understood very broadly. He regards man as the repository of certain natural rights, and the withholding of these rights impoverishes him. Integral to man's rights is that of freedomhuman, religious, academic, political, civic, social and moral. Since al-Siba'i represents a central tendency in Egypt's socialism as certified by Egypt's top leadership, ${ }^{24}$ what he has to say is a good indication of the content of democratic cooperative socialism. Al-Siba'i, like al-Razzaz and many others who have influenced Egypt's Arab socialism, treats freedom in an ennumerative and descriptive manner. ${ }^{25}$ He takes his cue from social democratic theory in assuming man's essential goodness rather than his evil nature (unlike monarchism and fascism, for example). Freedom is here seen to be a gift from his Creator to which man happily reaches out because it is in his nature to want to be free, productive, creative.

There is, thus, in Egypt's socialist thought, no doctrine of freedom as such. Freedom as a condition of struggle with, and release from, necessity seems to be a perspective alien to this thought. This is the case for even the pro-Egyptian Ba'thi theoretician, 'Abdallah al-Rimawi, for whom " "Man as he really lives in society" is the origin, axis, and causal force of his historical development'.26 In short, al-Rimawi starts toward a conceptual, rather than descriptive and ennumerative, perspective on freedom

23 Atif Ahmad, 'The Individual and Society,' in Political and Social Thought in the Contemporary Middle East, Kamal Karpat, ed. (New York: Praeger, 1968), p. 226.

${ }_{24}$ 'We are assured from authoritative sources that [al-Siba'i's book] is considered to be of the utmost importance in providing form, direction and legitimacy to the social system emerging in present-day Egypt. It is considered to be, in brief, a major statement of ideology for Egyptian socialism'. See George H. Gardner and Sami A. Hanna, 'Islamic Socialism', The Muslim World, LVI, 2 (April 1966), p. 73.

${ }_{25}$ Mustafa al-Siba'i, Ishtirakiyyah al-Islam [The Socialism of Islam] (Cairo: al-Dar alQawmiyyah li al-Taba'ah wa al-Nashr, 1960), pp. $35 \mathrm{ff}$. While he is a Syrian, Egypt claims his thought for Egypt's socialism.

${ }^{26}$ Rimawi, Al-Qawmiyyah wa al-Wahdah fi al-Harakat al-Qawmiyyah al-'Arabiyyah alHadithah [Nationalism and Unity in the Modern Arab Nationalist Movements] (Cairo: Dar al-Ma'arif, 1961), p. 463, cited in Karpat, p. 151. 
(by asserting that man's biological needs, curiosity, will and freedom, and desire for equality collectively are responsible for historical movement and development); but he stops short of a deeper analysis and in fact repudiates idealism, metaphysics, entropy, infinity and dialectical materialism 'in so far as they constitute a method of inquiry into man, his society, culture and history'. 27 Unfortunately al-Rimawi is reduced to making ex-cathedra statements that man is free by nature; and we are once again struck by the proclivity for avoiding abstract theoretical explication in the eagerness to postulate certain givens.

Among Egyptian socialists, it is 'Ismat Sayf al-Dawlah who carries the debate to higher and more sophisticated levels. While for the most part the routine analyses of socialism rest content with categoric affirmations concerning the realization of freedom under Arab unity and the Arab nation, Sayf al-Dawlah closely investigates the relationship between freedom and necessity. In keeping with his dialectical method, he concludes that without the doctrine of necessity, there could be no such thing as freedom. 'Necessity', he writes, 'is the primary condition that makes any act in the future possible'. Or later: the occurrence of things that we decide to do depends on the scientific inevitability of the various laws of the universe. Freedom, therefore, is a 'movement the end of which is the future that has not yet occurred but which is heading toward occurrence in the chosen way'. Sayf al-Dawlah rejects the idea that freedom is a phenomenon of spontaneous passage of past into future. 28

Plainly put, Sayf al-Dawlah is asserting that any world view which insists that history is a sequence of chance events of nature and human behavior taking place haphazardly cannot possibly have anything to do with human freedom. If anything, freedom is an actively and wilfully affirmed force. Consequently, the author attacks deterministic philosophies and refutes Bergsonian vitalism. The notion of entelechy (some life force immanent in the universe) is one that destroys the possibility of freedom. On the other extreme is existentialism, which treats freedom as a function of purely individual choice; this seems to be an outgrowth of the Kantian perspective that freedom ultimately is the exercise of one's judgment in acting based on one's perception of what is morally appropriate for the self to do. ${ }^{29}$ This, too, is unsound for Sayf al-Dawlah, whose solution of the problem of freedom might be said to rest between vitalism and Kantian inspired existentialism. The irony that Soviet Marxism also attempts to tread a middle ground between deterministic and idealist outlooks on freedom leads one to try to capture the difference

27 Idem.

${ }^{28}$ Sayf al-Dawlah, Usus al-Ishtirakiyyah, pp. 133-4.

${ }^{29}$ For Kant "freedom meant "autonomy". It is the expression of the principle that the moral subject has to obey no rules other than those which he gives to himself'. Ernst Cassirer, The Myth of the State (New Haven: Yale University Press, 1946), p. 235. 
between the Soviets and Egyptians concerning this aspect of their ideologies.

This is not easily done, however, since both handbooks, The Fundamentals of Marxism-Leninism and The Foundations of Arab Socialism are extremely cautious. The Soviet's position is that 'Taking necessity as the basis, dialectical materialism simultaneously recognizes the possibility of the freedom of man. The real freedom of man consists not in an imaginary dependence of man upon natural and social laws ... but in understanding these laws and acting according to them'. ${ }^{30}$

Yet, this seems very much akin to the Egyptian version (published later in time). For, despite his stated objections, Sayf al-Dawlah's position is that genuine freedom means 'the regulation of the world's movement by that which is within man, based on determinative laws which are or can be known'.31

But, Sayf al-Dawlah notes, the Soviets will only go so far and no further. Thus, they adhere to the thesis that man is capable of understanding the laws of nature and social development; and by their knowledge of these laws, they necessarily take their place in the movement of history. Yet, this is tantamount to dismissing man altogether. For the logical conclusion of the Soviet position is that man can only understand, not change, historical development.

The quarrel that the Egyptian has picked with the Soviets thus boils down to the ability or inability of man to change the course of history. The maximum the Soviets are willing to concede is that man uses his knowledge of the laws of nature and society to make them serve him. But this does not constitute an admission that man can alter the course of things The emphasis appears to be on man being able to make his life more efficient, more secure, more enjoyable. The Egyptian, by contrast, wants to go further and acknowledge that man does have the power to alter the broad sweep of historical development that encompasses him.

The Egyptian agrees with the fundamental principle that all movement is dialectical in nature. Hence, his quarrel with Marxism-Leninism is not that it is based on the dialectical principle. Rather, he repudiates the materialist parameters that allegedly restrict man's influence to one of passive comprehension of the world about him In place of materialism he erects the dialectics of man, a more dynamic paradigm which claims 'the law of dialectics is a law peculiar to man, alone'. Man's development in history takes place according to characteristic laws that are specific to him (al-qawanin al-naw'iyyah al-khassah bi al-insan) And these laws all

${ }^{30}$ O. V. Kuusinen, et al., eds., Osnovy Marksizma-Leninizma, 2nd ed. (Moscow: Gosudarstvennoe Izdatelstovo Politicheskoi Literatury, 1962), pp. 113-14. Among the determinists are listed Islam and Holbachs (the French materialist philosopher); among the idealists, of course, Hegel.

31 Sayf al-Dawlah, Usus al-Ishtirakiyyah al-'Arabiyyah, p. 149. 
concern freedom: to exist, to choose, to know, to do, to reason, and so on:

Freedom rightly understood consists of knowing how man guides the movement of evolution by his subjecting both matter and thought to his will. When the common man says: 'I am free to do what I want,' it is he alone who is free to want and do. It is this that is his characteristic law, the likes of which cannot be found in a material nature that does not want or an absolute idea that cannot do. ${ }^{32}$

Thus, neither matter nor Absolute Idea are in and of themselves a primal generating force of existence. To Sayf al-Dawlah the dialectics operate in the following manner: problems emerge in society (thesis); man addresses himself to these problems and formulates a theoretical resolution for each (antithesis); man resolves the conflict by putting into practice the mental resolution he had already devised in the preceding stage (synthesis). Again, Sayf al-Dawlah on freedom:

Freedom is the ability to develop, it is the understanding and resolution of a problem, and the implementation of the solution by action. Thus, we have arrived at that standard that we are examining in order to know what accords with freedom and what is considered tyranny. For making freedom consists of the motion of dialectics, with the knowledge we have that man is the only disputant, enables us to be superior to all these materialist or idealist theories which deprive man of his dialectical capacity and subject him to fatalism regarding nature, history, spirit or thought; in short, which subject man to an external force. ${ }^{33}$

\section{FREEDOM IN MARX, MARXISM-LENINISM AND EGYPT'S SOCIALISM : SOME CLARIFICATIONS}

With this survey of the shortcomings of Hegelianism and MarxismLeninism, Sayf al-Dawlah boldly asserts that it remains for the Arab world to establish a genuine concept of freedom to contrast with the failures of the bourgeois and communist models. In this, the thirteen centuries of Islam 'in which we have always glorified the freedom of man', ${ }^{34}$ give Arab civilization a tremendous advantage.

32 lbid., pp. 149-50.

33 lbid., pp. 158-9.

${ }^{34}$ Ibid., p. 171. Here, Sayf al-Dawlah slips into apologia. Does he have in mind the Qur'an's prescriptions and the traditions and sayings of the Prophet, Muhammad? Or does he mean rather the precedents set by the first four Caliphs and the four great jurisprudents of Islamic law, Hanbal, Hanafi, Shafi'i and Maliki? Or does he really mean the 1,300 years of political and social experience of Muslim civilization? From the language, he seems to mean basically the last. It seems he feels that freedom has been glorified all along the line of Islam's existence. But can we really take him seriously? Thirteen hundred years is a long time, and many tyrannies intervened along the way. Since freedom has already been defined by him in terms of man's ability to develop based on unhindered and unrestricted existence, choice, opinion, argumentation, action, has Muslim man according to these criteria, really been free? To take one aspect of Islamic theory, how can Sayf al-Dawlah take this position in view of the "closing of the gates of ijtihad' (independent judgment) at the end of the third century A.H. And what about the decision long ago adopted in favor of orthodoxy and against the mu'tazilah on the issue of predetermination and free will ? 'The self-responsible architect of one's own life' idea that best describes freedom as an ethical component is completely alien to thirteen centuries of Islamic civilization. [The term is that of Herbert Marcuse, Soviet Marxism (New York: Vintage Books, 1961), p. 181.] If Sayf al-Dawlah means, by contrast, that Islam has glorified the freedom of man in a 'civil liberty' sense (Marcuse), an examination of the legal and social 
Apart from his claim for Islam, Sayf al-Dawlah (and many other writers, too) runs into serious trouble by confusing Marx with Soviet Marxism. (Here, Marx's plaintive assertion that 'I am not a Marxist' comes into mind.) What Sayf al-Dawlah presents as the 'dialectics of man' is perhaps not all that original, after all. Consider the following: 'For Marx, as for Hegel, freedom meant self-determination in accordance with one's inner constitution; it meant not being determined from without, by one's relations to other things, but by the logical principles of one's own development'. ${ }^{35}$ It was Marx, was it not, who said that the dialectics take place through man's actions. 'Marx's view does not reduce man to a passive acceptance of, and acquiescence in, unchangeable and unchallengeable circumstances'.36 Marx took an activist view of man, who could truly change his life's chances and circumstances in concert with his fellow men. Nothing could be further from the truth than that Marx's view of freedom was that it came as a mere epiphenomenon to the interplay of material forces whose mechanistic movement heads toward ultimate liberation:

Marx [identified] thought with human self-consciousness, and the motive power of history with a specifically human spirit of essence... Marx in consequence rejects the non-human Absolute Idea as something alien to humanity and to man and regards its alleged social manifestation (e.g. Hegel's rational State and its organs) as attempts to erect authoritarian social institutions 'dominated by a spirit not their own'. ${ }^{37}$

In other words, neither machines nor impersonal ideational forces free men in Marx's thought, yet this is the kind of picture that Egyptian theoreticians of Arab socialism appear to be presenting to their readers about Marxian socialism. To cite another leading authority on the subject:

[To Marx] history is not the succession of the effects on men of external environment or of their own unalterable constitutions, or even the interplay between these factors, as earlier materialists had supposed. Its essence is the struggle of men to realize their full human potentialities; and since they are members of the natural kingdom (for there is nothing that transcends it), man's effort to realize himself fully is a striving to escape from being the plaything of forces that seem at once mysterious, arbitrary and irresistible, that is, to attain to the mastery of them and of himself which is freedom. Man attains this subjugation of his world not by increase in knowledge obtained by contemplation (as Aristotle had supposed) - but by activity-by labor-the conscious molding by men of their environment and of each other-the first and most essential form of the unity of will and thought and deed, of theory and practice. ${ }^{38}$

systems of Muslim theorists will show that this is at least moot. Obviously, Islam does not advocate slavery and does champion the right of man to be his own spokesman in his relation. ship to God. But it is not here a question of such matters. Islam never experienced a separate freedom function as civil liberty ('being able to do what is not prohibited by law'-Marcuse) since there was never any truly autonomous political system in Islam.

${ }^{35}$ Eugene Kamenka, The Ethical Foundations of Marxism (New York: Praeger, 1962), p. 23.

${ }^{36}$ Shlomo Avineri, The Social and Political Thought of Karl Marx (Cambridge: Cambridge University Press, 1968), p. 92.

37 Kamenka, Ethical Foundations, p. 24.

${ }^{38}$ Sir Isaiah Berlin, Karl Marx: His Life and Environment, 3rd edition (London: Oxford University Press, 1963), p. 128, emphases supplied. 
Hence, while the distinction concerning freedom between the Soviet variation on Marx and that of Sayf al-Dawlah's Egyptian Arab socialism seems at least implicitly clear, it is difficult to find such a distinction between the Egyptian version and that of Marx himself. Nevertheless, the distinction exists, and it lies, as shall be seen below, in the role and function of religion. Egyptian theorists are obsessed with refuting the Soviet perversion of Marx and remain virtually insensitive to the humanistic foundations of Marxian ethics. Where, in the Egyptian exegesis of Marxism, is the concept of the alienation of man from his own labor, with its attendant point of departure in the human condition ? ${ }^{39}$ Why the incessant harping on the threat of the 'machine'? Perhaps this is the normal reaction of adherents of a body of thought that is still in the gestation stage and that is still shaky in its foundations. In any case, closer to the truth is the judgment that 'Karl Marx ... came to Communism in the interests of freedom, not of security'. ${ }^{40}$ In a word, the strange and unreal picture painted by Egyptian theoreticians of robot-like machines forming the foundations of a socialist society and thrusting man aside appears to be a polemical device by which these regime spokesmen attack and isolate the radical left internal opposition. ${ }^{41}$ In doing this they corner the market, as it were, on the humanistic bases of socialism and assert a continuity with Islamic ethics. Forging such links of continuity with the ethical foundations of the traditional Islamic culture is an appropriate task for the Egyptian theorists. But this does not mean that Marx may be excluded from those who, as socialists, aspire to a society rooted in freedom.

\section{ISLAMIC ETHICS AND DEMOCRATIC COOPERATIVE SOCIALISM}

The most articulate spokesman of the relationship between Islam and socialism in the Arab world is the Syrian, Mustafa al-Siba'i. His work, The Socialism of Islam, has already been mentioned above. Socialism having emerged as a doctrine of social and economic organization, one normally does not conceive of it in relationship to transcendental thought. Yet, Egyptian socialists strongly urge the view that not only are the two compatible, but that Islam is the socialist religion par excellence.

This is interesting in view of the early bias in Islam against the universality of reason and the religion's integral concepts of the oneness of God and the uncreated Qur'an. The anti-rational posture, enshrined in

${ }_{39}$ 'To be radical is to grasp things by the root. But for man the root is man himself', Marx, Contribution to the Critique of Hegel's Philosophy of Right, cited by Roger Garaudy, Marxism in the Twentieth Century (Tr. René Hague; New York: Charles Scribner's Sons, 1966), p. 76. Marx begins and ends with man in his thinking about the establishment of socialist society. It is misleading and wrong, therefore, to claim that Arab socialism stands out in contrast to Marxism in the sense of humaneness and humanism.

40 Kamenka, Ethical Foundations, p. vii.

41 Not that the radical Left does not unhesitatingly cleave to the Soviet Marxist version. In fact, very few intellectuals in Egypt have sought to distinguish themselves as Marxists, rather than Marxist-Leninists. 
the victory over the mi'tazilah in the ninth century, would appear on the surface to be inconsistent with a body of thought and action-socialismwhose structure has been built on libertarian foundations. ${ }^{42}$ The argument revolves around the perception of Islamic thought: is it rooted in magic, fatalism, nonchalant occasionalism? Or does it, in fact, adhere root and branch to a rationalist framework? According to Rodinson, the wellknown French sociologist of Islam, the Islam of the Qur'an 'causes the intervention of reason and rationality to a higher degree than the ideologies reflected by the Old and New Testaments'.43 But even Rodinson, whose objective is to show that there is nothing inherent in Islam that forbids capitalist development, does not go so far as to say that in medieval Islam (cf. the Islam of the Qur'an), reason and rationality were brought to bear at a high level of intellectual experience. Indeed, he admits the supremacy of fatalism in Islamic thought (although he does deny that proof exists to show that this thought is fatalistic because it is Islamic).

To Egyptian theorists, the concept of socialism signifies 'a human tendency which finds clear expression in the teaching of the prophets and in the work of reformers from earliest times'. If Islam is directed against man's use of property in order to exploit his fellow men and to achieve social equality and justice through the instrument of state regulation, then Islam indeed has been from the very beginning a socialist system. ${ }^{44}$ But has this been the case?

Egypt's Arab socialists feel that for man an orientation toward collectivity is a normal state of being. The cultural heritage of Islam has already placed Muslim man squarely in the midst of the ummah, or community of true believers. Egyptians have therefore always shared a communal experience, apart from which an individual's life would be meaningless. ${ }^{45}$ Islam, however, also sanctions ownership of private property. Moreover, there is really nothing in the Islamic Weltanschauung that seriously hinders the development and growth of a capitalist system. ${ }^{66}$ After all, Islam derived from a mercantile tribal organization in which commerce constituted the crucial means of exchange. The Qur'an and Islamic jurisprudence based on it recognize the right to own and inherit property,

\footnotetext{
${ }^{42}$ But cf. St. Simon and his 'New Christianity'. 'The association of socialism with democracy took time to establish itself; that of socialism with republicanism (let alone atheism) was far from obvious, at any rate to radicals outside France.... By [the 1890s], however, socialism as a doctrine was already fully formed, and the attitudes it encouraged, although tinged with religious sentiment, were subversive of the social teachings which the churches had traditionally made their own'. George Lichtheim, The Origins of Socialism (New York: Praeger, 1969), p. 8.

${ }^{43}$ Maxime Rodinson, Islam et capitalisme (Paris: Editions du Seuil, 1966), p. 112.

${ }^{44}$ Siba'i, Ishtirakiyyah al-Islam, pp. 5 ff.

${ }^{45}$ Gustave von Grunebaum, Modern Islam: The Search for Cultural Identity (New York: Vintage Books, 1964), p. 246.

${ }^{46}$ Rodinson, Islam et capitalisme, passim.
} 
wealth, possessions. Some of the most detailed parts of the Qur'an itself are devoted to legal rights of inheritance, for example. In theory, of course, everything in a Muslim's possession is ultimately the property of Allah. The implication is thus that God is the 'owner' of all possessions in the Islamic ummah. However, even the successors to the Prophet of God did not have the right in law to dispossess or expropriate errant citizens of the ummah, except for apostasy. 47 Also, Islam has a vigorous concern with the terrestrial life and urges man to live a full life in the here and now.

Consequently, one notes a dualism in Islam with respect to man's place in the world. The two, individualism and collectivism, work at cross-purposes with one another and serve to complicate the current attempts to find a place for Islam in the modern Muslim community. For example, to Kamal al-Din Mahmud Rif'at, a major regime theoretician of socialism, Islam represents a social system more than a religious creed. $\mathrm{He}$ approvingly notes that its role in leading toward spiritual perfection well accords with the aims of socialism: equality, individual dignity and ethical relations among men. Rif'at notes that in the UAR, 'free man is the basis of a free society'. Freedom of the individual human being is the 'greatest incentive of the [revolutionary] struggle and the primary guarantee against negativism, indifference and hopelessness'. However, since man tends to be egotistical in his behavior, the role of religion is 'to subject the mind of the individual to the common interest, to regulate its behavior so that it accords with, not contradicts, the life of society'.48 Religion and socialism, far from being incompatible, are well suited to the Egyptian reality in Rif'at's mind. The one thing to fear is attempts by reactionaries (the Muslim Brotherhood, the bourgeoisie), to employ religion to retard social progress.

Egypt's Charter of National Action (1962) ensures an important place for religious and spiritual values in the socialist society that Egypt is seeking to build. The thrust of the official regime position appears to be that Islam represents a system of social justice. Islam shares with other religious creeds the concept of fraternity and right conduct among all men. It insists that true piety, not merely earthly prosperity, is the path toward acceptance by God. Islam, like Christianity, does make invidious distinctions between the meek, downtrodden, poor, and the wealthy,

${ }^{47}$ This right of expropriation established itself with the onset of the dynastic principle, especially in the Ottoman Empire. There, it became a potent political weapon against the Sultan's opponents.

48 Rif'at, 'Al-Tajribah al-Ishtirakiyyah fi al-Jumhuriyyah al-'Arabiyyah al-Muttahidah', [The Socialist Experiment in the UAR], al-Katib, special supplement, No. 75 (June 1967), pp. 5, 9. 'Free man is the basis and capable builder of the free society' is an idea directly from the National Charter, the official programmatic statement of Egypt's socialism. The literature is voluminous on this subject but tends to be didactic. For another view, see Dr. Yahya al-Jamal, 'Al-Ishtirakiyyah bayna al-Wahdah wa al-Ta'addud' [Socialism Between Unity and Diversity], al-Fikr al-Mu'asir, No. 10 (Dec. 1965), pp. 40-7. 
prosperous and arrogant. This has led the late President 'Abd al-Nasir to remark that 'Islam was the first revolution which posed socialist principles in matters of justice and equality'. 49

The ethical Problematik involves man's relationship to other men and society. If one approaches this from the perspective of the proper ends of mankind, what may one conclude about Egypt's socialism and its conception of this important question? For the ancient Greeks, man's end was a life of reason, whose control over the physical universe served to permit his self-realization. In classical Islam man's true end was service to God, and only in such submission could one perfect himself. In the modern nation-State, where the constitution (since 1971, anyway) declares Islam to be the religion of the State, what are the ends of man? The response given thus far in Egypt has been surprisingly non-revolutionary in nature. It has been shaped by persons whom we might regard as neo-Keyneseans, whose political views have been shaped by a strong dosage of anticolonial nationalism. The moderate and humanistic outlook of these individual theorists seems close to that of Fabian socialism. Society exists to realize the potentialities of the individual, according to this line of thinking. Society 'must secure for every man wide scope to allow him to realize his potentialities and inclinations in a way for which his abilities qualify him, without limitations or restrictions of poverty, inheritance, milieu, occupation or oppressive laws'.50 Otherwise put, society must allow opportunity for each man to go as far as his qualifications will enable him to go, everything else being equal. This is not a redistributive theory of society. Indeed, there is nothing radical here about what amounts to a social welfare state position. And, crucially, al-Razzaz does not advocate structural transformation of society on behalf of any single social class or force.

Religion plays a role as the leaven that allows the society to grow and develop itself without facing the dangers of material forces and the general tendency toward randomness and entropy that secularization tends to foster. This contemporary view represents a change in perspective as far as religion is concerned. These present-day socialist theoreticians seem to have latent social contract ideas. Accordingly, society comes into being not necessarily because it is the natural human community to work the will of God on earth. Rather, society arises in order to enable men the better to realize their own human possibilities. The socialist theorists are therefore stressing the existence of a separate political function and sphere, reserving for religion a different and more private realm. Man, therefore,

${ }^{49}$ Speech commemorating the fourth anniversary of the UAR, cited in al-Ahram, February 23, 1962. This brings to mind Lichtheim's plaint that to be a Christian, a Buddhist (a Muslim) and to profess belief in socialism does not make it true that the religions-Christianity, Buddhism (Islam) - are inherently socialist. Origins of Socialism, p. 221, n. 5.

50 Al-Razzaz, Ma'alim al-Hayat al-'Arabiyyah al-Jadidah, pp. 48 ff. 
will resort to Islamic morality and ethics in his inner life only, within the bosom of his family.

Gathering together some of the strands of the foregoing discussion, the striking thing about Egypt's socialism is that religion is an important factor. The Egyptians regard both Islam and socialism as supremely ethical statements of the human condition. If Marx would assert that labor is the force that will end man's alienation from others and from himself, Egypt's Arab socialism holds that belief in a transcendental metaphysic will serve this purpose. (This leaves aside entirely the notion entertained by both Marxism and Egypt's socialism that social organization will prove indispensible for ending the alienation perceived by each.)

Altogether, the question of how crucial a role Islam will play in the construction of socialism in Egypt depends upon whom one reads. Rif'at, as a spokesman for the regime, tends to see it more as a tool to reinforce the bonds between individual and group. Thus, one might say that to him, socialism is more the ultimate purpose, religion being a helpful means to its achievement. Siba'i, by contrast, tends to see a far more autonomous role for religion. Islam is the crucial variable, for him, without which socialism can become a tyranny. ${ }^{51}$ Socialism needs Islam. Islam makes socialism possible. Rif'at never even raises the question of secularization as containing the seeds of potential tyranny.

We may note that, despite their differential emphases, both wings of Egypt's socialism tend to agree that the proper ends of mankind can only be achieved if one acknowledges some scope for spiritual forces. In this context, Egyptians either refuse to pose the question of the primacy of mind or matter as an absured dichotomy (Sayf al-Dawlah); or else they invariably declare the precedence of mind. One of the most detailed Egyptian rebuttals to the Soviet view that 'material philosophy is the reliable weapon that defends man from the pernicious influence of spiritual reaction's2 has sought to marshal evidence from the early European socialists themselves to support his 'mind over matter' thesis. ${ }^{53}$ Human society requires religion, and spirituality must supervene when the issue is joined over mind and matter. The National Charter, in more restrained language, nevertheless links the attainment of justice (a proper end for mankind) to 'an unshakeable faith in God, His prophets and His sacred messages'.54

\footnotetext{
51 See his disparaging comments about communism and the U.S.S.R., Ishtirakiyyah alIslam, pp. 10-13.

52 Kuusinen, et al., Osnovy Marksizma-Leninisma, p. 15.

53 Muhammad Tal'at 'Isa, 'Al-Nuzum al-Diniyah wa al-Ishtirakiyyah: Dirasah li alMuqawwimat al-Ruhiyyah li al-Ishtirakiyyah al-'Arabiyyah muqaranah li al-Ishtirakiyyah al-Alamiyyah' [Religious Systems and Socialism: A Study of the Spiritual Elements of Arab Socialism Compared to International Socialism], al-Majallah al-Misriyyah li al-'Ulum al-Siyasiyyah, No. 49 (April 1965), pp. 61-96.

${ }_{54}$ United Arab Republic, The Charter (Cairo: Information Department, 1962), p. 8.
} 


\section{CONCLUSIONS}

It is somewhat ironical that the Egyptians use that Marxist term, 'scientific socialism', to characterize democratic cooperative socialism. The problems of cause and effect, necessity and freedom, and man and God are areas of disagreement, as well as of agreement, between Egyptian and Marxist socialism. Although the differences are striking, one must not lose sight of the similarities.

The main difficulty in differentiating the Egyptian variant of socialism from that of Marxism lies, as we have seen, in an inability to distinguish Marx's contributions from those of his vulgarizers, Engels, Lenin and Stalin. The Polish philosopher, Henryk Skolimovski,55 has usefully separated out Marxism from the Marxism of Engels and Lenin and from 'Machiavellian Marxism'. If Marxism may be regarded as philosophy, Marxism-Engelsism-Leninism as ideology, and Machiavellian Marxism finally as the 'opportunism of the Party', we can better appreciate that what goes under the name of Marxist thought is not so monolithic as the Egyptian theorists consider it to be.

We know that Marx regarded social conflict and contradiction as the causal agents of change. The Egyptians do not agree and insist that development occurs according to a dynamic of fusion, not fission. This means two important things: (1) unity must be achieved by a process of reconciliation and harmonization-it is the precondition for successful socialist construction; (2) the motor of man's historical development is the nation-state idea, founded on a common basis of ethnicity and religious belief (Rodinson's 'dynamique globale').

As far as the metaphysical question of freedom versus necessity is concerned, Marxist theory is not entirely different from Egypt's Arab socialism. The emphasis both place on man as the creator of his history is notable.56 But, in point of fact, the Egyptians ignore this aspect of Marxism completely. Thus, to Marx, man is the substance of existence, the world around him is the form. Yet, this position tends to be eclipsed in the mind of most persons, who refer to the universal social laws for which Marxist theory is so famous as evidence of the determinism of Marxism.

Egypt's Arab socialism attaches importance to the dignity of man. It denies that man is determined in his behavior. However, its leading philosopher, 'Ismat Sayf al-Dawlah, does admit that necessity operates in the physical universe and that natural laws occur irrespective of man's existence and/or involvement. Yet, due to certain "special laws characteristic of

\footnotetext{
ss Skolimovski, 'Polish Marxism', paper delivered at the University Seminar on Communism, Men's Faculty Club, Columbia University, New York, New York, December 17, 1969.

56 'History does nothing... rather, it is man, actual and living man, who does all this'. Karl Marx and Friedrich Engels, The Holy Family, cited in Adam Schaff, Marxism and the Human Individual (New York: McGraw Hill, 1970), p. 139.
} 
man' the human being can overcome natural forces. Sayf al-Dawlah accuses Marxism of imposing a rigid framework on man, who must cope with his situation as best he can. Yet, Marx himself wrote: 'man is no abstract being, squatting outside the world'. ${ }^{57}$ And Marx showed his indignation with the view of man as the plaything of forces and in 'fantastic isolation' from reality. ${ }^{58}$ Marx deplored the idea that man should only try to comprehend his universe, criticizing all philosophers because they 'have only interpreted the world, in various ways', and noting, instead, that 'the point, however, is to change it'. 59

Of course, Egypt's Arab socialism breaks sharply with Marxism on the question of transcendentalism. It is possible, evidently, for Christians, for example, to be Marxists; and at least one scholar of international repute has called himself a 'transcendental Marxist'.60 Marx's views on religion are too well known to be introduced here. The Egyptian socialist interpretation of Marxism is that because of its rejection of organized religion, it rejects morality and ethics as a whole. ${ }^{61}$

Even on the question of religion, however, it is useful to distinguish within Egyptian socialism between those who regard Islam as indispensable for socialism and those who consider it in more instrumental terms. In the latter case, Islam becomes an aid to secularization, although this is never admitted. Marx's point about religion was that, at worst, it caused man to lose himself; and, at best, it prevented him from finding himself. And the reason for this, according to Marx, is that organized religion proceeds on the premise that it makes man-that is, it makes him whole. In reacting to this assumption, Marxism holds that it is man who makes religion, and he has the power to unmake (i.e. to unmask) it. The Egyptian theoreticians sidestep this issue and reinforce Islam's basically ethical positions. Accordingly, they deny that religion at its most noble and perfect state exploits man and causes his alienation. To the contrary, man can only find himself by communing with God.

How socialist is Egyptian socialism? This is a question that has been on the tongue of many people, both within Egypt and outside the country.

57 Karl Marx, Critique of Hegel's Philosophy of Right, Joseph O'Malley, ed. (Cambridge: Cambridge University Press, 1970), p. 131.

${ }_{58}^{8}$ Karl Marx and Friedrich Engels, The German Ideology, R. Pascal, ed. (New York: International Publishers, 1947), p. 15.

${ }^{59} \mathrm{Karl}$ Marx, 'Theses on Feuerbach', in Marx and Engels: Basic Writings on Politics and Philosophy, Lewis S. Feuer, ed. (Garden City, New York: Anchor Books, 1959), p. 245.

${ }^{60}$ Claude Lévi-Strauss, who meant by this phrase that if religious belief depends on social structure and processes, nonetheless there is such a dense interplay between the two that 'it is not simply a matter of one level "determining" the other...', Nur Yalman, 'Some Observations on Secularism in Islam: The Cultural Revolution in Turkey', Daedalus, CII, 1 (Winter 1973), p. 143.

${ }_{61}$ Marx's preference for Prometheus over Christ because Prometheus defended man against the gods, whereas Christ defended God against man, is worthy of note here. See Lloyd D. Easton and Kurt H. Guddat, eds., 'Introduction', Writings of the Young Marx on Philosophy and Society (Garden City, New York: Anchor Books, 1967), p. 5. 
In particular, what is its relationship to Marxism, since, in the words of one leading authority on Middle East politics, 'the study of ideology has received its greatest impetus from Marx ...'62 In the realm of metaphysics it has been shown, the two systems share some common premises and even conclusions about man. Yet, they remain distinct from one another, and this is attributable in the last analysis to the significant gaps in the respective historical background and foundations of European and Middle East societies.

${ }^{62}$ Leonard Binder, The Ideological Revolution in the Middle East (New York: John Wiley, 1964), p. 108. 